\title{
Role of Alcoholic Extracts of Eruca sativa or Petroselinum crispum on Dioxin-Induced Testicular Oxidative Stress and Apoptosis
}

\author{
Hussam A. El-Gayar ${ }^{1}$, El-Sayed M. El-Habibi' ${ }^{2}$ Gamal M. Edrees ${ }^{2}$, Eman T. Salem ${ }^{2}$, Mona S. Gouida ${ }^{3}$ \\ ${ }^{1}$ Urology and Nephrology Center, Mansoura University, Mansoura, Egypt \\ ${ }^{2}$ Zoology Department, Faculty of Science, Mansoura University, Mansoura, Egypt \\ ${ }^{3}$ Mansoura University Children Hospital, Genetic Unit, Mansoura University, Mansoura, Egypt
}

\begin{abstract}
The present study was undertaken to examine the antioxidant potential of alcoholic extract of Petroselinum crispum (Pc) or Eruca sativa (Es) against TCDD testicular toxicity in male albino rats. Forty two adult male rats were allocated to one of seven groups, six rats each: Control (G1), Corn oil (G2), PC (G3), Es (G4), TCDD (G5), Pc + TCDD (G6) and Es + TCDD (G7). All treatments were made by gastric intubation for 5 weeks. TCDD treated rats showed significant increase in testes lipid peroxidation products (LPO), and protein carbonyl content (PC) as well as nitric oxide (NO) associated with significant decreased superoxide dismutase (SOD) \& catalase (CAT) activities, reduced glutathione (GSH) level and increased apoptosis as indicated by transforming growth factor $\beta 1$ (TGF $\beta 1)$ and CD95. Whereas, alcoholic extract of either Pc or Es have an effective antioxidant property as observed by the normalization of antioxidant enzymes and decreased levels of LPO, PC and NO in testes co-treated with Pc or Es. Also, alcoholic extract of Pc or Es have significantly decreased apoptosis induced by TCDD. It can be concluded that alcoholic extract of Pc or Es suppress the toxic effects of TCDD by its free radical-scavenging and potent antioxidant activity.
\end{abstract}

Keywords: TCDD, Testes, Oxidative stress, Apoptosis, Eruca sativa, Petroselinum crispum.

\section{Introduction}

During the past decade, concern over the involvement of oxygen free radicals in various diseases has escalated. Deleterious effects of ROS often occur as a consequence of an imbalance between the formation and inactivation of these species leading to irregularities in cellular physiology and different pathological conditions [1]. Abundant evidence leaves no doubt that (ROS) and the resulting oxidative stress have a pivotal role in apoptosis in testes, particularly in environmental-contamination cases [2].

Dioxin (TCDD) a persistent endocrine-disrupting environmental contaminant, is generated during industrial processes like incineration of medical wastes, chlorine bleaching of paper and pulp and manufacture of pesticides. Home-heating systems, exhaust from cars and cigarette smoke have been found to contain trace quantities of dioxin [3]. Due to its lipophilic properties, slow metabolism and excretion, TCDD readily accumulates in body [4]. The majority of the toxic effects of TCDD are related to its role in activating the aryl hydrocarbon receptor (AhR) [5]. Polyunsaturated fatty acids of sperm membrane are the target of free radicals generating lipid peroxides (LPO) which are highly toxic and induce testicular injury [6]. Reproductive tissues have been found to be very sensitive targets of dioxin. Exposure to TCDD has been reported to cause low sperm counts and decreased fertility [7]. Also, it decreases the activity of enzymes that protect against oxidative damage in testicular tissue [8]. As there are inverse relationship between ROS level and antioxidant enzymes activities, therefore, the administration of various natural or synthetic antioxidants has been shown to be benefit in the attenuation of diseases induced by oxidative stress [9]. The protective role of dietary polyphenols particularly fruits and vegetables have been established. Dietary polyphenols as Es or Pc exhibit many biologically significant functions, such as protection against oxidative stress, and degenerative diseases [10].

Es is one of the nutritious green-leafy vegetable. It belongs to the Brassicaceae family. It has a high content in vitamin $\mathrm{C}$, vitamin $\mathrm{A}$, carotenoids, and polyphenols [11]. It possess free radical scavenging and antioxidant activity [12]. It was reported that the ethanolic extract of Es plant has androgenic activity or stimulating testicular steroid production as well as increase spermatogenesis [13].

Pc, a leafy vegetable belongs to the family Umbelliferae is known as a rich source of ascorbic acid, carotenoids, flavonoids, coumarins, and tocopherol [14], and scavenge hydroxyl radical induced membrane oxidation [15].

The aim of the present study was to investigate the protective effect of ethanolic extract of either Pc or Es on TCDD-induced toxicities in testes of albino rats.

\section{Materials and Methods}

\subsection{Chemicals}

TCDD (Cas No. 1746-01-6) was purchased from SigmaAldrich (Saint Louis, Missouri, USA). Ethanol was purchased from (Al-Gomohria Company for chemicals, Abou-Zaabal, Egypt). Corn oil was purchased from local store. All other chemicals were of analytical grade

\subsection{Animals}




\section{International Journal of Science and Research (IJSR) \\ ISSN (Online): 2319-7064 \\ Index Copernicus Value (2013): 6.14 | Impact Factor (2014): 5.611}

This study was performed on male Albino rats initially weighing (160-180g). Rats were obtained from the Institute of Ophthalmic Disease Research, Cairo, Egypt. They were housed in stainless steel cages in an artificially illuminated and thermally controlled room $\left(22-25^{\circ} \mathrm{C}\right.$ and $12 \mathrm{~h}$ light / dark cycle). They were fed on standard diet and given water ad libitum for one week for acclimation prior to the experimental work. All animals received human care in compliance with the guidelines of the Animal Care and Use Committee of Mansoura University.

\subsection{Preparation of plant extracts}

Pc and Es were purchased from a local market in Mansoura City, Egypt. Ethanolic extract of Pc and Es were prepared according to methods of [16], [17]. Briefly, Five hundred $g$ of coarse powder of aerial parts of the plant were macerated in 3 liters of $96 \%$ ethanol and allowed to stand at room temperature for about $72 \mathrm{~h}$ using percolation method. The percolate was collected and dried under reduced pressure in vacuum. The extract was suspended in distilled water before administration.

\subsection{Detection of total phenolic compounds in Pc and Es leaves extract}

Detection of total phenolic constituents in alcoholic extract of either Pc or Es was carried out according to [18]. The total phenolic compounds of the ethanolic extracts of Pc and Es were 320 , and $185 \mathrm{mg} \mathrm{GAE} / \mathrm{g}$ dry wt, respectively.

\subsection{Evaluation of Antioxidant activity DPPH radical scavenging activity}

Scavenging activity of DPPH antioxidant assay was estimated as reported by [19]. The antioxidant activity (IC50) of ethanolic extracts of Pc and Es were 246.7 and $217.1 \mu \mathrm{g} / \mathrm{ml}$, respectively.

\subsection{Experimental protocol}

Forty two male rats were allocated to one of seven groups, 6 rats each. Normal control (G1) group was fed on standard diet without any supplementation. Corn oil (G2) group treated with corn oil as vehicle at dose of $2 \mathrm{ml} / \mathrm{kg}$ b wt The Pc (G3) group, treated with Pc alcoholic extract at a dose $2 \mathrm{~g}$ / $\mathrm{kg} \mathrm{b}$ wt The Es (G4) group, treated with Es alcoholic extract at a dose $500 \mathrm{mg} / \mathrm{kg} / \mathrm{b}$.wt. The TCDD (G5) group, received daily $100 \mathrm{ng} / \mathrm{kg} /$ diluted in $2 \mathrm{ml}$ corn oil. The Pc +TCDD (G6) group was treated with $\mathrm{Pc}$ and TCDD by the same dose, route as group 3 and 5. The Es +TCDD (G7) group was treated with Es and TCDD by the same dose, route and time as group 4 and 5. All treatments were made by gastric intubation and the experimental period was 5 weeks.

\subsection{Sample collection and preparation of testes homogenate}

At the end of the experimental period, the animals were fasted overnight, weighed and sacrificed under slight ether anesthesia. Testes were rapidly excised from each animal, and washed free of blood with $0.9 \% \mathrm{NaCl}$ solution. They were then blotted over a piece of filter paper. The tissues were washed with a $50 \mathrm{mM}$ (sodium phosphate buffer saline $\mathrm{PH}$ 7.4) in an ice-containing $0.1 \mathrm{mM}$ EDTA to remove any RBCs and clots. A known weight of right testes was homogenized in cold distilled water using homogenizer, centrifuged at $860 \mathrm{Xg}$ for $20 \mathrm{~min}$ at $4^{\circ} \mathrm{C}$ and the resultant supernatant was frozen at $-20{ }^{\circ} \mathrm{C}$ for estimating MDA, PC, SOD, CAT, and GSH. Other known weight from the right testes were homogenized with phosphate buffer solution $(\mathrm{PH}$ 7.4) and centrifuged at $10.00 \mathrm{Xg}$ for 20 minutes at $4^{\circ} \mathrm{C}$ and supernatant was separated for $\mathrm{NO}$ analysis.

\subsection{Determination of malondialdehyde (MDA) level}

The level of malondialdehyde (MDA) as a marker of lipid peroxidation, in testes were estimated according to the modified method of [20].

\subsection{Determination of protein carbonyl content (PC)}

Protein carbonyl content in testes were measured according to [21].

\subsection{Determination of nitric oxide (NO) level}

Nitric oxide (NO) level in testes was measured after [22] by the determination of total nitrate and nitrite concentrations.

\subsection{Determination of superoxide dismutase activity (SOD)}

Superoxide dismutase activity (SOD) in testes was determined by the method of [23].

\subsection{Determination of catalase activity (CAT)}

Catalase activity in testes was determined by the method of [24].

\subsection{Determination of reduced glutathione (GSH) level}

Reduced glutathione (GSH) level in testes was estimated according to the method of [25].

\subsection{Determination of nucleic acid in testes}

Nnucleic acids was extracted as reported by [26].

\subsection{Determination of DNA content}

DNA content was estimated in testes homogenate using the method reported by [27].

\subsection{Determination of RNA content:}

RNA content was determined by using the method of [28].

2.17. Quantification the frequency of transforming growth factor $\beta 1$ (TGFß1) cells $(\%)$ and CD95 cells (\%) by flow cytometry

A portion of the left testes was minced in Tris buffer $(\mathrm{pH}=7.4)$, centrifuged at $860 \mathrm{X} \mathrm{g}$ for $5 \mathrm{~min}$ at $4^{\circ} \mathrm{C}$ and the resultant supernatants were frozen at $-20{ }^{\circ} \mathrm{C}$ until use. The frequency of TGF $\beta 1$ cells (\%) was determined according to 


\section{International Journal of Science and Research (IJSR) \\ ISSN (Online): 2319-7064}

Index Copernicus Value (2013): 6.14 | Impact Factor (2014): 5.611

the manufacturer's instructions (ab31013, Abcam biochemicals $\left.{ }^{\circledR}, \mathbf{U K}\right)[29]$. The frequency of CD95 cells (\%) was determined as [30]. in testes tissue in the different groups and were quantified using the G1 peak staining with iodide [31] using Becton FACSC flow cytometry (Becton Dickinson Corporation, USA).

\subsection{Statistical analysis}

All values are presented as mean \pm SE. Differences were considered to be significant at $p<0.05$. One-way analysis of variance (ANOVA) and post-hoc test were used to determine differences between groups. The SPSS/PC program (version 17; SPSS, Chicago, Illiniois, USA) was used for statistical analysis [32].

\section{Results}

As shown in figure (1) TCDD treated group showed significant increase $(\mathrm{P}<0.001)$ in testes MDA, PC, and NO level $(192 \%, 206 \%, 271 \%$, respectively) as compared with the control. On the other hand, testes SOD, CAT activity as well as GSH, DNA and RNA content were significantly decreased $(\mathrm{P}<0.001)$ in these rats as compared to control $(65 \%, 34 \%$ and $55 \%, 68 \%$ and $65 \%$, respectively).

Concerning Pc + TCDD group, a significant decrease $(\mathrm{P}<0.001)$ in testes MDA, PC and NO level $(66 \%, 70 \%$ and $59 / \%$, respectively) were observed, while SOD, CAT activity, and GSH, DNA and RNA level were significantly increased $(138 \%, 208 \%, 158 \%, 128 \%$ and $129 \%$, respectively) as compared to TCDD treated rats .
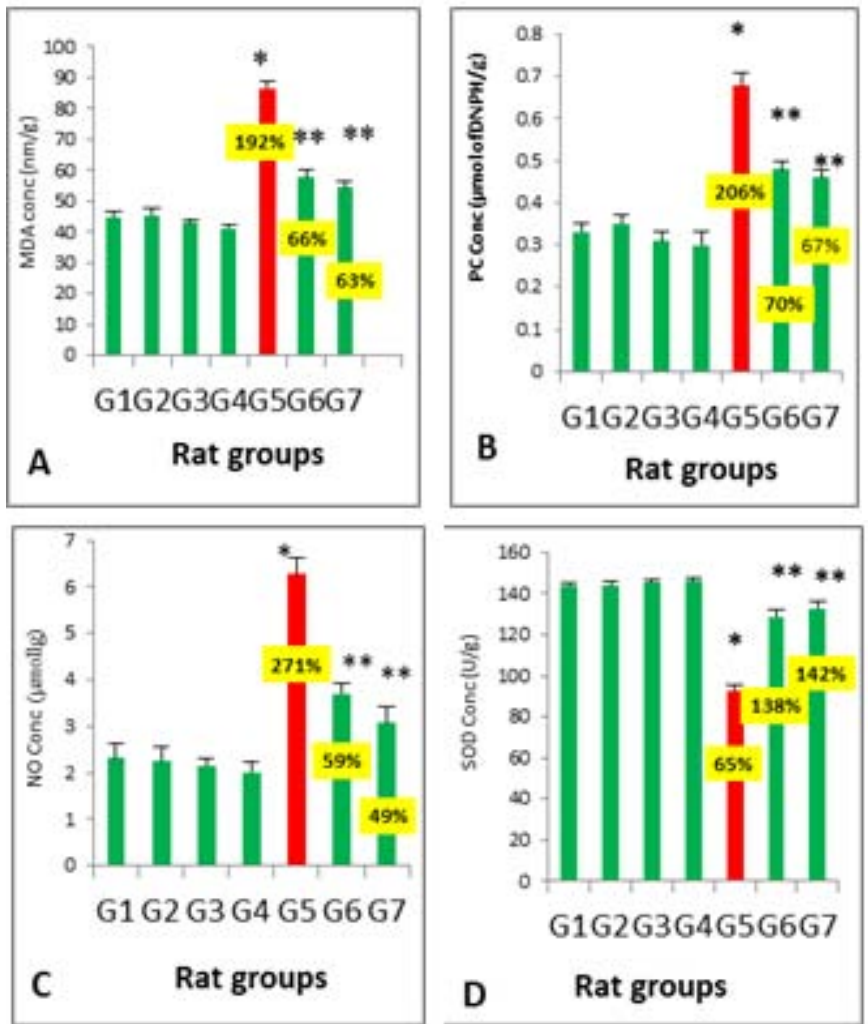
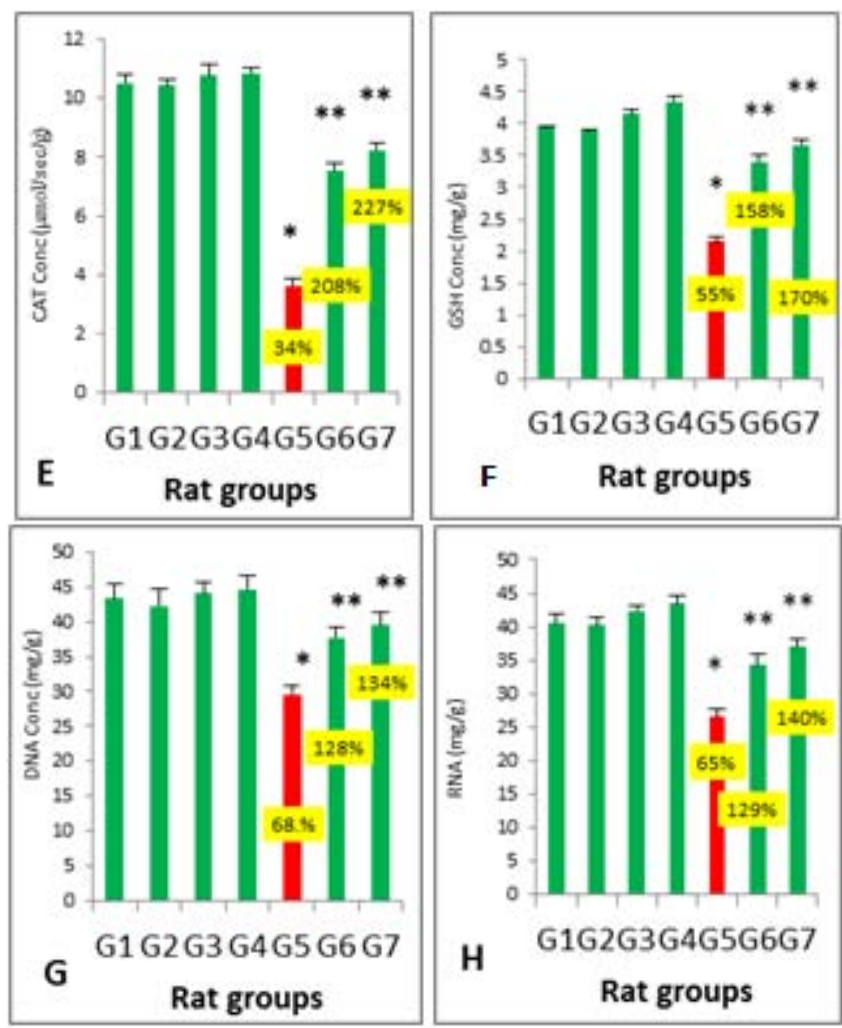

Figure 1: (A): lipid peroxidation products (MDA), (B): protein carbonyl content (PC), (C): nitric oxide (NO), (D): Supperoxide dismutase (SOD), (E): Catalase (CAT), (F): reduced glutathione (GSH), (G): Deoxyribonucleic acid

(DNA), and (H): ribonucleic acid (RNA) in testes of

different groups rats * Denotes $P<0.001$ significant differences compared with control. Denotes $* * P<0.001$, significant differences compared with TCDD treated rats.

Regarding to Es + TCDD group testes MDA, PC and NO were significantly decreased $(\mathrm{P}<0.001)$ as compared to TCDD treated rats $(63 \%, 68 \%$ and $49 \%$, respectively), while SOD, CAT and GSH were significantly increased $(\mathrm{P}<0.001)$ as compared to TCDD treated rats $(143 \%, 228 \%, 170 \%$, $134 \%$ and $140 \%$, respectively).

As shown in figure (2) there was significant increase $(\mathrm{P}<0.001)$ in the frequency of TGF- $\beta 1$ and CD95 cells (192\% and $164 \%$, respectively) in the testes of TCDD treated rats as compared with control. In Pc + TCDD group there was significant decrease $(\mathrm{P}<0.001)$ in testes TGF $\beta 1$ and CD95 (54\% and 63\%, respectively) as compared with TCDD treated rats. In Es + TCDD group there was significant decrease $(\mathrm{P}<0.001)$ in testes TGF $\beta 1$ and CD95 (65\% and $76 \%$, respectively) as compared to TCDD treated rats. 


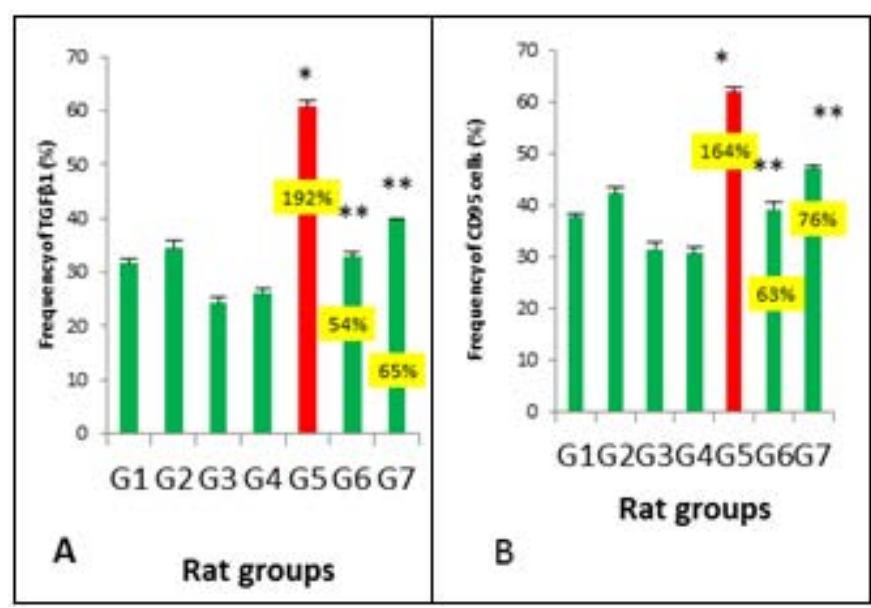

Figure 2: Effect of alcoholic extract of either $2 \mathrm{~g} / \mathrm{kg}$ Petroselinum crispum $(\mathrm{Pc})$ or $0.5 \mathrm{~g} / \mathrm{kg}$ Eruca sativa (Es) on Frequency of TGF $\beta 1$ (A) and CD95 (\%) (B) in testes tissue of rats treated with $100 \mathrm{ng} / \mathrm{kg} / \mathrm{day}$ TCDD in the different groups. Values are presented mean \pm SEM.$*$ Denotes $P<0.001$ significant differences compared with control. Denotes ** $P<0.001$, significant differences compared with TCDD treated rats.

\section{Discussion}

Dioxin (TCDD) is known to cause many toxic effects that vary greatly in different tissues. The testes has been reported to be among the most sensitive organs to TCDD exposure [33] since the balance between pro-oxidants and antioxidants is vital for normal testes function and sperm fertilization ability. So, much focus has been given to reactive oxygen species (ROS), a group of highly reactive oxidizing agents that are able to damage almost all molecular species in spermatozoa, including lipids, proteins and nucleic acids.

The results of antioxidant activity of the alcoholic extracts of Pc or Es agree with previous reports showing that total phenolic compounds from plants were potent $\mathrm{O}_{2} \cdot-$ scavengers [34]. Moreover, several studies have shown that the pharmacological effects of phenolic compounds are related to their antioxidant activity, which can be due to their ability to scavenge $\mathrm{OH} \bullet$ and $\mathrm{O} 2 \cdot-[\mathbf{1 2}],[35]$. Our results in conjunction with the others mentioned above, suggest that phenolic compounds could constitute one of the active components of either Pc or Es

Because testicular membrane is rich in fatty acids, which are prone to undergo peroxidative decomposition. ROStriggered lipid peroxidation reactions generate a range of reactive carbonyl species (RCS), and these RCS spread and amplify ROS- related injury [6]. They also reported that LPO is a characteristic manifestation of oxidative damage in cells and tissues. Results of present study demonstrate increase in LPO similar to earlier reports by [36].

Oxidative stress caused by cytochrome P450 induction is one of the typical stresses of dioxin poisoning, TCDD may triggers stress response via "stress-activated kinase pathways" is stimulatin of the cellular production of cytokine/autocrines, particularly growth factors, an explantion which in accordance with [37]. Increase in LPO in these results owing to increase in ROS or alternatively dioxin may inhibit non enzymic antioxidant phase II enzymes and antioxidant enzymes which is supported by the findings that dioxin reduces antioxidant molecules and antioxidant enzymes [38].

Elevation in PC, DNA, and RNA contents in dioxin treated rats in the present study are in agreement with [39]. These data may be due to elevation of ROS which start chain reaction resulting in oxidation of protein and nucleic acid.

Another pathway involved in the testicular damage is the inflammatory process. NO plays crucial roles inducing an inflammatory response and their toxicity multiplies when they react with oxygen or with superoxide to form peroxynitrite, which is a powerful oxidant and cytotoxic agent that damages biomolecules such as proteins, lipids and nucleic acids [40]. In the present study, we found that alcoholic extract of either Pc or Es was active and it may also have powerful effects for the scavenging of NO. The increase in NO level is in TCDD treated rats also observed by [41]. This elevation may be a result of activation of iNOS genes via oxidative stress resulting in excessive NO generation [42].

The present study show a decrease in SOD activity in the dioxin treated rats, a result which agree with [6]. The decrease of SOD activity in testes in TCDD treated rats may be due to the enhanced lipid peroxidation or inactivation of antioxidant enzymes. This favors the accumulation of superoxide radicals, which inturn stimulate lipid peroxidation [43]. Also, decrease in SOD activity favors the accumulation of superoxide radicals, which inturn inhibit CAT [44]. This decreased CAT activity in the dioxin treated group is previously reported by [8]. The decreased CAT activity results in the augmentation of $\mathrm{H}_{2} \mathrm{O}_{2}$ generation [39]. CAT activity may be diminished as a result of accumulation of superoxide radicals [44]. The elimination of $\mathrm{H}_{2} \mathrm{O}_{2}$ in G6G7 is affected by CAT, an explanation agree with [45]. Decrease in GSH level in this study in TCDD group may be due to increased utilization of GSH for metabolism of lipid hydroperoxides by GPx or interaction of GSH with free radicals, this view agree with [8]. Depletion of GSH may be result of increased generation of superoxide radicals with lipid peroxidative response [46]. The alcoholic extract of either $P c$ or $E s$ were able to partially prevent TCDD induced decay of antioxidant enzyme activities. This may be due to the presence of phenolic acids constituents that have scavenger role, an explanation which in accordance with [47].

Tansforming growth factor beta (TGF- $\beta 1$ ) is proinflammatory cytokines and profibrogenic mediator [48]. In addition, increased TGF- $\beta$ mRNA and/or protein expression has been reported in testicular pathologies [49]. In the present study TCDD induces significant increase in the levels of TGF- $\beta 1$ cytokine. This result is in consistent with [50]. This elevation is accompanied by increased MDA, DNA, RNA and NO levels, together with low level of SOD, CAT and GSH, indicating the interplay between oxidative stress and TGF $\beta 1$. [51] have demonstrated that TGF $\beta 1$ stimulates the production of ROS. 


\section{International Journal of Science and Research (IJSR) \\ ISSN (Online): 2319-7064 \\ Index Copernicus Value (2013): 6.14 | Impact Factor (2014): 5.611}

CD95 is a subgroup of tumor necrosis factor (TNF) receptor superfamily which mediates apoptosis. In the present study, TCDD has been found to significantly enhance the testicular level of CD95 (Fas) which is positively correlated with ROS and is negatively correlated with antioxidant enzymes. This result is in consistent with [52]. This elevation may be due to apoptosis triggered by PAHs through alterations of lipid rafts composition and remodeling of the plasma membrane [53].

The results of the present study demonstrated that, alcoholic extracts of either Pc or Es showed superior antioxidant system evidenced by SOD, CAT activity and GSH level near control group. The co- administration of either alcoholic extract of Pc or Es concomitant with TCDD reduced the lipid peroxidation, and $\mathrm{PC}$ as well as NO level in testes associated with the elevations of antioxidant enzymes, SOD, CAT activity and GSH level. The protective effect of Pc or Es against TCDD- induced oxidative stress in our study could be either direct by inhibiting lipid peroxidation and scavenging free radicals or indirect through the enhancement of the activity SOD, and CAT as well as GSH. These properties could be attributed to active ingredients of Es including alkaloids, glycosides, flavonoids, saponins, terpens and steroids, while that of Pc leaf of alcoholic extract contain flavonoids, coumarins, and terpenes [13], [35].

Also, alcoholic extract of either Pc or Es treatment reduced the increase of iNOS expression in the testicular tissue of TCDD-treated rats; this effect probably results from the reduction of iNOS pathway, probably this effect of alcoholic extract due to its decreasing impact on ROS levels and inhibitive influence on p38-MAPK activation [54].

In conclusion, TCDD induced oxidative stress and apoptosis in rat testes. The alcoholic extract of either Pc or Es seem to have protective effect on TCDD-induced testicular oxidative damage. This highlights the potential therapeutic use of this phenolic compound in the prevention of oxidative stress mediated testicular damage.

\section{Conflict of Interest}

The authors declare no financial or commercial conflict of interest.

\section{References}

[1] Halliwall, B, Free radicals, proteins and DNA: oxidative damage versus redox regulation," Biochemistry Society Transactions, 24, 1023-1027, 1996.

[2] Mathur P,P., D'Cruz, S.C., 2011.The effect of environmental contaminants on testicular function. Asian J Androl.13 (4):585-591.

[3] Fiedler, H., Hutzinger, O., Timms, C.W., 1990. Dioxins: sources of environmental load and human exposure. Toxicology and Environmental Chemistry.29 (3), 157234.

[4] Enan, E., El-Sabeawy, F., Overstreet, J., Matsumura, F., Lasley, B., 1998. Mechanisms of gender specific TCDD induced toxicity in guinea pig adipose tissue. ReproductiveToxicology.12, 357-369.
[5] Mandal, P.K., 2005. Dioxin: a review of its environmental effects and its aryl hydrocarbon receptor biology. J Comp Physiol B. 175, 221-230.

[6] Singh, M., Kapoor, A., Bhatnagar, A.. 2015. Oxidative and reductive metabolism of lipid-peroxidation derived carbonyls. Chem Biol Interact. 234, 261-273.

[7] Gray, L.E Jr., Ostby, J., Furr, J., Wolf, C.J., Lambright, C., Parks, L., 2010. Effects of environmental antiandrogens on reproductive development in experimental animals.Human Reproduction Update. 7(3), 248-264.

[8] Ciftci, O., Aydin, M., Ozdemir, I., Vardi, N., 2012. Quercetin prevents 2,3,7,8-tetrachlorodibenzo-p-dioxininduced testicular damage in rats. Andrologia. 44 (3), 164-173.

[9] Flora, S.J., 2009. Structural, chemical and biological aspects of antioxidants for strategies against metal and metalloid exposure. Oxid Med Cell Longev. 2(4),191206.

[10]Han, X., Shen, T., Lou, H., 2007. Dietary Polyphenols and Their Biological Significance. Int. J. Mol. Sci. 8, 950-988.

[11] Martinez-Sanchez, A., Gil-Izquierdo, A., Gil, M.I.. Ferreres, F., 2008. A comparative study of flavonoid compounds, vitamin $\mathrm{C}$, and antioxidant properties of baby leaf Brassicaceae species, J Agric Food Chem. 56, 2330-2340.

[12] Sarwar Alam M, Kaur G, Jabbar Z, Javed K, Athar M. 2007. Eruca sativa seeds possess antioxidant activity and exert a protective effect on mercuric chloride induced renal toxicity. Food Chem Toxicol.45(6), 91020.

[13] Hussein, Z. F.. 2013. Study the Effect of Eruca Sativa Leaves Extract on Male Fertility in Albino Mice. Journal of Al-Nahrain University.16 (1), 143-146

[14] Petrolini, F.V., Lucarini R, de Souza, M.G., Pires, R.H., Cunha, W.R., Martins, C.H., 2013. Evaluation of the antibacterial potential of Petroselinum crispum and Rosmarinus officinalis against bacteria that cause urinary tract infections. Braz J Microbiol. 44(3),829834.

[15]Fejes, S., Blazovics, A., Lemberkovics, E., Petri ,G., Sz"oke, E., Kery, A., 2000. Free radical scavenging and membrane protective effects of methanol extracts from Anthriscus cerefolium L. Hoffm.) and Petroselinum crispum(Mill.) nym. ex A.W. Hill. Phytother Res.14 (5), 362-365.

[16]Al-Howiriny, T., Al-Sohaibani, M., El-Tahir, K., Rafatullah, S., 2003. Prevention of experimentallyinduced gastric ulcers in rats by an ethanolic extract of "Parsley" Petroselinum crispum. Am. J. Chin. Med. 31(5), 699-711.

[17] Alqasoumi, S., 2010. Carbon Tetrachloride-Induced Hepatotoxicity: Protective Effect of ,Rocket ${ }^{\text {ee }}$ Eruca sativa L. in Rats. Am. J. Chin. Med. 38 (1), 75-88.

[18]Blainski, A., Lopes, G.C., de Mello, J.C., 2013. Application and analysis of the folin ciocalteu method for the determination of the total phenolic content from Limonium brasiliense L. Molecules. 18(6), 6852-6865.

[19] Yen, G.C., Duh, P.D., 1994. Scavenging Effect of Methanolic Extracts of Peanut Hulls on Free-Radical and Active-Oxygen Species J. Agric. Food Chem.42 (3), $629-632$ 


\section{International Journal of Science and Research (IJSR) \\ ISSN (Online): 2319-7064}

Index Copernicus Value (2013): 6.14 | Impact Factor (2014): 5.611

[20] Ohkawa, H., Ohishi, N., Yagi, K., 1979. Assay for lipid peroxides in animal tissues by thiobarbituric acid reaction. Ana. Biochem. 95, 351-358.

[21][21] Smith, CD., Carney, J. M., Starke-Reed, P. E., Oliver, C. N., Stadtman, E. R., Floyd, R. A., Markesbery, W. R., 1991. Excess brain protein oxidation and enzyme dysfunction in normal aging and Alzheimer disease. Proc. Nat. Acad. Sci. 88, 1054010543.

[22] Montgomery, H.A.C., Dymock, J. F., 1961. Colorimetric determination of nitrite oxide. Analyst. 86: 414-417.

[23] Nishikimi, M., Appaji, N., Yagi, K., 1972. The occurrence of superoxide anion in the reaction of reduced phenazine methosulfate and molecular oxygen. Biochem. Bioph. Res. Common. 46 (2), 849-854.

[24] Aebi, H., (1974). Catalase: In: Methods of enzymatic analysis analysis, Bergemeyer, $\mathrm{H} \mathrm{V}$ (ed), Academic Press, New York, NY, USA. pp: 673-684.

[25]Beutler, E., Duron, O., Kelly, B. M., 1963. Improved method for the determination of blood glutathione. $\mathrm{J}$ Lab Clin Med.61,882-888.

[26] Melmed, R.N., El-Aaser, A.A., Holt, S.J., 1976. Hypertrophy and hyperplasia of the neonatal rat. Exocrine pancreas induced by administration of soybean tyrosine inhabitor. Biochem. Biophys. Acta. 421, 280 288.

[27] Dische, Z., Schwarz, K., 1937. Microchemical Methods for determining various pentoses in the presence of one anotherand of hexoses. Mikrochim Acta. 2, 13-19.

[28] Mejbaum, W., 1939. Estimation of small amounts of pentose especially in derivatives of adenylic acid. Z. physiol. Chem. 258, 117-120.

[29] Tribukait, B., Moberger, G., Zetterberg, A., 1975. Methodological aspects for rapid flow cytofluorometry for DNA analysis of human urinary bladder cells. In Haenen, C., Hillen, H., Wessels, S, eds. Pluse cytophotometry, part 1. European Press Medicon, Ghent, 55-60.

[30] Cifone, M.G., De Maria, R., Roncaioli, P., Rippo, M.R., Azuma, M., Lanier, L.L., Santoni, A., Testi, R.. 1994. Apoptotic signaling through CD95 (Fas/Apo-1) activates an acidic sphingomyelinase. J Exp Med.180 (4), $1547-1552$.

[31] Riccardi, C., Nicoletti, I., 2006. Analysis of apoptosis by propidium iodide staining and flow cytometry. Nat Protoc.1(3), 1458-1461.

[32] Snedecor, C.W., Cochran, W.C., 1980. Statistical methods $\left(7^{\text {th }}\right.$ ed). Iowa state Univ. press, Ames, Iowa. 593.

[33] Schultz, R., Suominen, J., Värre, T., Hakovirta, H., Parvinen, M., Toppari, J., Pelto-Huikko, M., 2003. Expression of aryl hydrocarbon receptor and aryl hydrocarbon receptor nuclear translocator messenger ribonucleic acids and proteins in rat and human testis. Endocrinology.144 (3), 767-776.

[34] Mišan, A., Mimica-Dukić, N., Sakač. M., Mandić, A., Sedej, I., Simurina, O., Tumbas, V., 2011. Antioxidant activity of medicinal plant extracts in cookies. J Food Sci.76 (9), C1239-44.

[35] Chaves, D.S., Frattani, F.S., Assafim, M., de Almeida, A.P., de Zingali, R.B., Costa, S.S.. 2011. Phenolic chemical composition of Petroselinum crispum extract and its effect on haemostasis. Nat Prod Commun. 6(7), 961-964.

[36] Sönmez M, Türk G, Çeribaşı AO, Sakin F, Ateşşahin A. 2011. Attenuating effect of lycopene and ellagic acid on 2,3,7,8-tetrachlorodibenzo-p-dioxin-induced spermiotoxicity and testicular apoptosis. Drug Chem Toxicol.34(4):347-356.

[37] Matsumura, F., 2003. On the significance of the role of cellular stress response reactions in the toxic actions of dioxin. Biochem Pharmacol. 66(4):527-540.

[38] Vijaya Padma, V., Kalai Selvi, P., Sravani, S., 2014. Protective effect of ellagic acid against TCDD-induced renal oxidative stress: modulation of CYP1A1 activity and antioxidant defense mechanisms. Mol Biol Rep. 41(7), 4223- 4232.

[39] Aitken, R. J., Roman, S.D., 2008. Antioxidant systems and oxidative stress in the testes. Oxid Med Cell Longev. 1(1), 15-24.

[40]Davis, K.L., Martin, E., Turko, I.V., Murad, F.. 2001. Novel effects of nitric oxide. Annu Rev Pharmacol Toxicol.41, 203-236.

[41]Li, Y., Chen, G., Zhao, J., Nie, X., Wan, C., Liu, J., Duan, Z., Xu, G., 2013. 2,3,7,8-Tetrachlorodibenzo-pdioxin (TCDD) induces microglial nitric oxide production and subsequent rat primary cortical neuron apoptosis through p38/JNK MAPK pathway. Toxicology.4(312), 132-141.

[42]Kleniert, H., Pautz, A., Linker, K., Schwarz, P.M. 2004. Regulation of the expression of inducible nitric oxide synthase. Eur J Pharmacol.500, 255-266.

[43] Oguz, F., Ciftci, O., Aydın, M., Timurkaan, N., Beytur, A., Altıntas, R., Parlakpinar, H., 2013. Aminoguanidine prevents testicular damage-induced-2,3,7,8tetrachlorodibenzo-p-dioxin (TCDD) in male rats. Andrologia. 45(4):225-231.

[44]Kono, Y., Fridovich, I., 1982. Superoxide radical inhibits catalase. J Biol Chem. 25,257(10):5751-5754.

[45] Peltola, V., Huhtaniemi, I., Ahotupa, M., 1992. Antioxidant enzyme activity in the maturing rat testis. J Androl. 13 (5), 450-455.

[46]Reed, D. J., 1990. Glutathione: toxicological implications Annu Rev Pharmacol Toxicol. 30, 603631.

[47] Beytur, A., Ciftci, O., Aydin, M., Cakir, O., Timurkaan, N., Yilmaz, F.. 2012. Protocatechuic acid prevents reproductive damage caused by $2,3,7,8$ tetrachlorodibenzo-p-dioxin (TCDD) in male rats. Andrologia. 44, Suppl 1,454-461.

[48]Ng, Y.Y., Chen, Y.M., Tsai, T.J., Lan, X.R., Yang, W.C., Lan, H.Y.. 2009. Pentoxifylline inhibits transforming growth factor-beta signaling and renal fibrosis in experimental crescentic glomerulonephritis in rats. Am J Nephrol. 29, 43-53.

[49]Gonzalez, C.R., Matzkin, M.E., Frungieri, M.B., Terradas, C., Ponzio, R., Puigdomenech, E., Levalle, O., Calandra, R.S., Gonzalez-Calvar, S.I.. 2010. Expression of the TGF-beta1 system in human testicular pathologies. Reprod Biol Endocrinol. 2(8), 148-158.

[50] Jin, M.H., Hong, C.H., Lee, H.Y., Kang, H.J., Han, S.W., 2008. Enhanced TGF-beta1 is involved in 2,3,7,8tetrachlorodibenzo-p-dioxin (TCDD) induced oxidative stress in C57BL/6 mouse testis. Toxicol Lett.178(3), 202-209. 


\section{International Journal of Science and Research (IJSR) \\ ISSN (Online): 2319-7064}

Index Copernicus Value (2013): 6.14 | Impact Factor (2014): 5.611

[51]Liu, R.M., Gaston Pravia, K.A., 2010. Oxidative stress and glutathione in TGF-beta-mediated fibrogenesis. Free Radic Biol Med.48(1),1-15.

[52] Camacho, I.A., Singh, N., Hegde, V.L., Nagarkatti, M., Nagarkatti, P.S., 2005. Treatment of mice with 2,3,7,8tetrachlorodibenzo-p-dioxin leads to aryl hydrocarbon receptor-dependent nuclear translocation of NF-kappaB and expression of Fas ligand in thymic stromal cells and consequent apoptosis in T cells. J Immunol.175 (1), 90103.

[53] Andreau, K., Leroux, M., Bouharrour, A., 2012. Health and cellular impacts of air pollutants: from cytoprotection to cytotoxicity. Biochem Res Int. 1, Article ID 493894- 493912.

[54] Camacho-Barquero, L., Villegas, I., Sa'nchez-Calvo, J.M., Talero, E., Sa'nchez-Fidalgo, S., Motilva, V., Alarco'n de la Lastra, C.. 2007. Curcumin, a Curcuma longa constituent, acts on MAPK p38 pathway modulating COX-2 and iNOS expression in chronic experimental colitis. Int Immunopharmacol.7, 333-342. 